Proceedings of the 35th European Peptide Symposium

\title{
Modulation of the properties of elastin-like polypeptides by structure variations
}

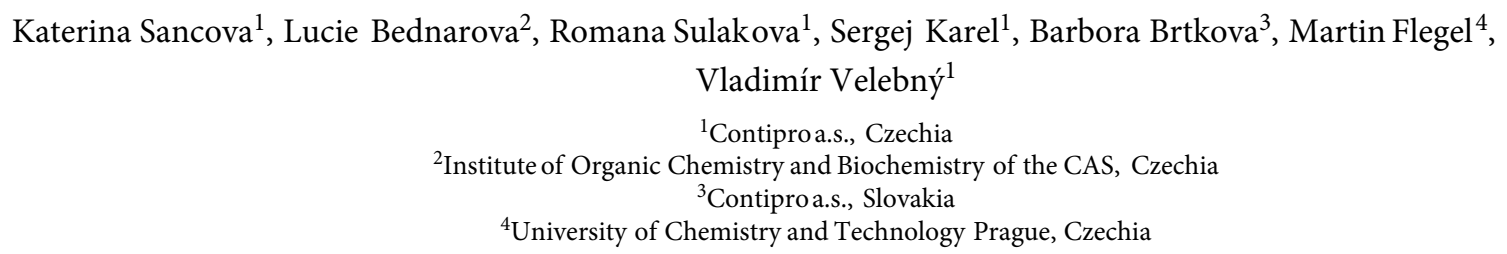

https://doi.org/10.17952/35EPS.2018.188

\section{Introduction}

Elastin-like polypeptides (ELPs) with VPGXG repeating sequence are artificial biomacromolecules derived from hydrophobic domain of tropoelastin.[1] Their characteristic feature is coacervation (self-association) characterized by transition temperature $\mathrm{T}_{\mathrm{t}}$. ELPs are soluble in water or buffer below its $\mathrm{T}_{\mathrm{t}}$ and they form $\beta$ structures and aggregates above its $T_{t}$. Up to date, the reversibility of the coacervation at specific temperature $T_{t}$ has been studied in many research areas, e.g. in drug delivery, protein purification and tissue engineering.[2] Moreover, the transition temperature can be modulated by both extrinsic ( $\mathrm{pH}$, ionic strength) and intrinsic factors (primary sequence and chain length).[3]

The aim of our study was to characterize secondary structure behavior and to define $T_{t}$ with respect to primary sequence of ELPs with general formula $\mathrm{H}(\mathrm{VPGLG})_{2}(\mathrm{VPGXG})_{2}(\mathrm{VPGLG})_{6}-\mathrm{OH}$, where we used the hydrophobic (Gly, Ala, Leu), hydrophilic (Gln, Asn, Tyr), acidic (Glu) and basic amino acids (His, Lys) as the variable element X.<smiles>[R]C(NC(=O)CNC(=O)C1CCCN1C(=O)C(N)C(C)C)C(=O)NCC(=O)O</smiles>

Scheme 1: Chemical structure of elastin-like polypeptide subunit VPGXG 
Table 1: Properties of prepared ELPS

\begin{tabular}{|c|c|c|c|c|}
\hline peptide & sequence & MW (Da) & $\mathrm{pl}^{*}$ & pl (X) \\
\hline ELP 1 & $\mathrm{H}$-(VPGLG) ${ }_{2}(\mathrm{VPGGG})_{2}(\mathrm{VPGLG})_{6}-\mathrm{OH}$ & 4301.47 & 6.09 & 5.97 \\
\hline ELP 2 & $\mathrm{H}-(\mathrm{VPGLG})_{2}(\mathrm{VPGAG})_{2}(\mathrm{VPGLG})_{6}-\mathrm{OH}$ & 4169.33 & 6.09 & 6.0 \\
\hline ELP 3 & $\mathrm{H}-(\mathrm{VPGLG})_{2}(\mathrm{VPGLG})_{2}(\mathrm{VPGLG})_{6}-\mathrm{OH}$ & 4253.51 & 6.09 & 5.98 \\
\hline ELP 4 & $\mathrm{H}$-(VPGLG) ${ }_{2}(\mathrm{VPGKG})_{2}(\mathrm{VPGLG})_{6}-\mathrm{OH}$ & 4283.53 & 10.72 & 9.74 \\
\hline ELP 5 & $\mathrm{H}-(\mathrm{VPGLG})_{2}(\mathrm{VPGHG})_{2}(\mathrm{VPGLG})_{6}-\mathrm{OH}$ & 4301.47 & 8.13 & 7.59 \\
\hline ELP 6 & $\mathrm{H}-(\mathrm{VPGLG})_{2}(\mathrm{VPGYG})_{2}(\mathrm{VPGLG})_{6}-\mathrm{OH}$ & 4353.53 & 5.96 & 5.66 \\
\hline ELP 7 & $\mathrm{H}-(\mathrm{VPGLG})_{2}(\mathrm{VPGEG})_{2}(\mathrm{VPGLG})_{6}-\mathrm{OH}$ & 4285.41 & 3.03 & 3.22 \\
\hline ELP 8 & $\mathrm{H}$-(VPGLG) ${ }_{2}(\mathrm{VPGQG})_{2}(\mathrm{VPGLG})_{6}-\mathrm{OH}$ & 4283.45 & 6.09 & 5.65 \\
\hline ELP 9 & $\mathrm{H}-(\mathrm{VPGLG})_{2}(\mathrm{VPGNG})_{2}(\mathrm{VPGLG})_{6}-\mathrm{OH}$ & 4255.39 & 6.09 & 5.41 \\
\hline
\end{tabular}

defined by Peptide Property Calculator.[4]

Solid Phase Peptide Synthesis and HPLC-MS purification

Peptides were synthesized using SPPS protocol by Fmoc/tBu strategy on Wang resin $(\mathrm{L}=1.12 \mathrm{mmol} / \mathrm{g}$, mesh 100 200). The coupling steps were performed using DIC/oxyma/AA in molar ratio 3/3/3. Subsequent Fmoc deprotection was provided by $20 \%$ piperidine in DMF for 5 and $15 \mathrm{~min}$. After synthesis, all peptides were cleaved by cleavage cocktail consisting of DMC/anisole/thioanisole/TIS/TFA (5/2/1/2/90).

Crude peptides were purified by RP-HPLC on Shimadzu L CMS-2020 system equipped with a splitter and ESI-MS and PDA detection at $210 \mathrm{~nm}$. The mobile phases were $0.1 \%$ formic acid in distilled water and acetonitrile. For separation, C18 column (Jupiter $4 \mu \mathrm{m}$ Proteo $90 \AA$ AXIA, $250 \times 10 \mathrm{~mm}$ ) was used. The flow rate was $2.5 \mathrm{ml} / \mathrm{min}$ in the suitable slow gradient profiles.

Temperature measurements

ELPs were dissolved in phosphate buffer ( $\mathrm{pH} 7.5)$ to concentration $0.1 \mathrm{mg} / \mathrm{ml}$. Peptides structural changes were studied by circular dichroism (CD) spectroscopy (Figure 1). Temperature dependence of CD spectra were measured in $1 \mathrm{~mm}$ quartz cell in spectral range from $190 \mathrm{~nm}$ to $280 \mathrm{~nm}$ with temperature step $10^{\circ} \mathrm{C}$, scanning speed $10 \mathrm{~nm} / \mathrm{minand}$ time response $8 \mathrm{sec}$. To compare molar ellipticity changes at two different wavelengths (Figure 2A), peptide sample was heated with gradient $1{ }^{\circ} \mathrm{C} / \mathrm{min}$ and for each measurement the temperature equilibration was $30 \mathrm{sec}$. Temperature interval was $5{ }^{\circ} \mathrm{C}$ to $90^{\circ} \mathrm{C}$. 

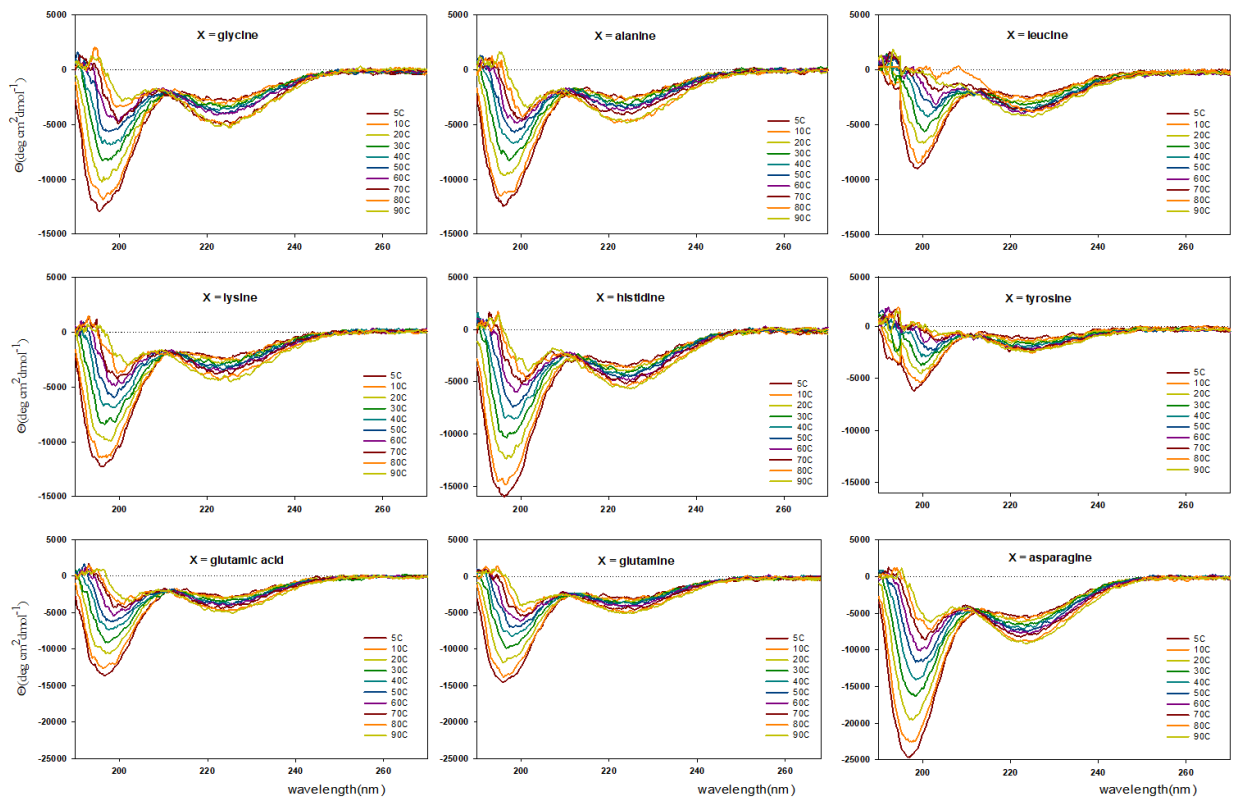

Figure 1: CD spectra of elastin like polypeptide ELP1-9. The CD spectra at low temperature are characterized by high proportion of random coil (distinct minimum at $197 \mathrm{~nm}$ ) and low proportion type II $\beta$-turns (lesspronounced minimum at $224 \mathrm{~nm}$ ). In general, the secondary structure distribution is gradually inverted with increasing temperature. The differences in intensity of CD spectra for discrete peptide is caused by presence of $\beta$-turn structure already presented at low temperature.

Turbidity profiles and transition temperatures(Figure 2B) were estimated using UV-Vis spectroscopy (OD at $400 \mathrm{~nm}$ ). The sample (concentration $1 \mathrm{mg} / \mathrm{ml}$ in phosphate buffer $\mathrm{pH} 7.5$ ) was placed in $1 \mathrm{~cm}$ quartz cell and continually stirred and heated with temperature gradient $1{ }^{\circ} \mathrm{C} /$ min in the temperaturerange from $10^{\circ} \mathrm{C}$ to $70^{\circ} \mathrm{C}$.

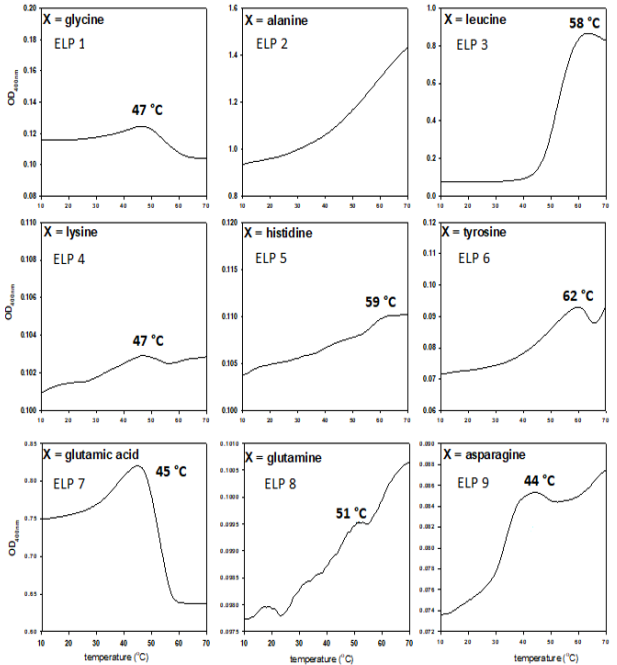

A

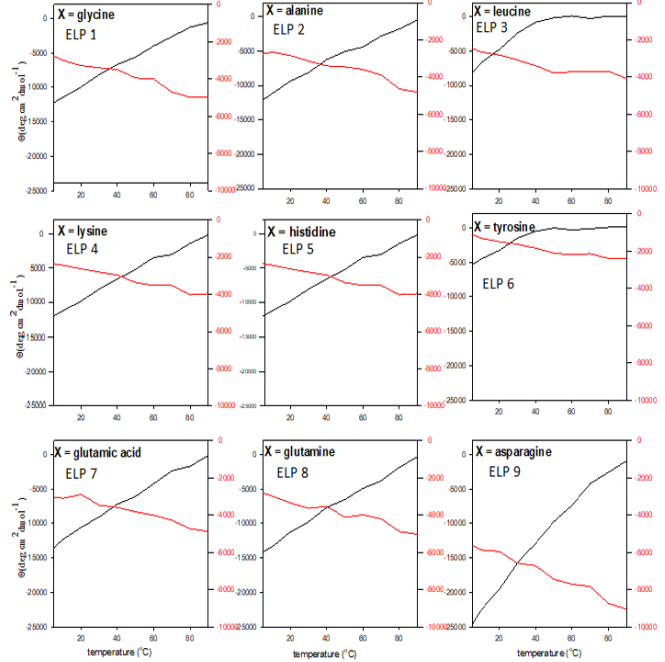

B

Figure 2: Temperature measurements: A) ELPs coacervation profiles and B) ELPs molar ellipticity $(\Theta)$ changes at $197 \mathrm{~nm}$ (black) and $224 \mathrm{~nm}$ (red)

\section{Conclusion}

Turbidity profile and transition temperature for each prepared ELP were estimated with exception of the peptide containing alanine, where aggregation was observed immediately after dissolving in PBS buffer. Pronounced coarcervation was observed for ELPs with hydrophobic $(\mathrm{L})$ or polar $(\mathrm{Q}$ and $\mathrm{N})$ and negative $(\mathrm{E}$ and $\mathrm{T})$ side chain.

To obtain the information of secondary structure dependency on temperature changes, CD spectroscopy was employed. For all studied ELPs, we observed higher portion of unordered conformation in combination with type 
II $\beta$-turns at low temperature $\left(5^{\circ} \mathrm{C}\right)$. The distribution of type II $\beta$-turns increased with rising temperature and simultaneously the distribution of unordered structures decreased. However, the presence of $\beta$-turn structures was observed for ELPs containing bulky side chains ( $T, N$ and L) or negative charge (E) at low temperature. ELPs with polar ( $\mathrm{Q}$ and $\mathrm{N}$ ) and negative (E) side chain showed pronounced structural transition from unordered structure to type II $\beta$-turns. On the other hand, saturation of $\beta$-turns if any was observed for peptides containing $\mathrm{X}$ with bulky side chain (L, K, H and T). For ELPs, the reversibility of their secondary structure changes with increasing and afterwards decreasing temperature was confirmed, but on the different time scale for discrete ELPs.

\section{References}

1. Foster, J. A.; Bruenger, E.; Gray, W. R.; Sandberg, L. B. J. Biol. Chem.1973, 248, 2876-2879

2. Aladini, F.; Araman, C.; \& Becker, C. F. W. J. Pept. Sci. 2016, 22(5), 334-342.

3. Chilkoti, A.; Christensen, T.; \& Mackay, J. Curr. Opin. Chem. Biol. 2006, 10(6), 652-657.

4. Peptide Property Calculator - Ver 3.1.; 2018, on-line 